\title{
UJI AKTIVITAS ANTIOKSIDAN EKSTRAK ETANOL BEE POLLEN LEBAH TRIGONA (Trigona itama)
}

\author{
Isna Wardaniati ${ }^{1}$, Surhiyatun Taibah ${ }^{1}$ \\ Faculty of Faculty of Medicine and Health Sciences , Universitas Abdurrab, \\ Indonesia \\ isna.wardaniati@univrab.ac.id
}

\begin{abstract}
Bee pollen have complex and diverse chemicals makes bee pollen have various properties, one of which is as an antioxidants. Bee pollen is one of the natural antioxidants source in the form of flavonoids, polyphenols and carotenoids. Antioxidants function as neutralizing free radicals, so that the body is protected from various kinds of degenerative diseases and cancer. The purpose of this study was to determine the antioxidant activity (AA) of the ethanol extract from bee pollen trigona (Trigona itama) using the $\beta$-carotene bleaching method by UV-Vis spectrophotometry. The results showed that the ethanol extract of bee pollen (Trigona itama) had an antioxidant activity value (AA) of $66.2 \%$ (intermediate) while ascorbic acid was a positive control of $97.7 \%$ (strong antioxidant). From the results of study it can be concluded that the ethanol extract from bee pollen trigona (Trigona itama) has efficacy as an antioxidant with an intermediate class of antioxidant (AA) activity.
\end{abstract}

Keyword: Bee pollen, trigona itama, antioxidants, $\beta$-carotene bleaching, spectrophotometry UV-Vis

ABSTRAK Bee pollen memiliki kandungan bahan kimia yang kompleks dan beragam membuat bee pollen mempunyai khasiat yang bermacam-macam, salah satunya adalah sebagai antioksidan. Bee pollen merupakan salah satu bahan yang mengandung antioksidan alami berupa flavonoid, polifenol dan karotenoid. Kandungan Antioksidan berfungsi sebagai menetralisasi radikal bebas, sehingga tubuh terlindungi dari berbagai macam penyakit degeneratif dan kanker. Adapun tujuan dari penelitian ini adalah untuk mengetahui aktivitas antioksidan (AA) ekstrak etanol bee pollen lebah trigona (Trigona itama) menggunakan metode $\beta$-karoten bleaching secara spektrofotometri Uv-Vis. Hasil penelitian menunjukkan bahwa ektrak etanol bee pollen lebah trigona (Trigona itama) memiliki nilai aktivitas antioksidan (AA) sebesar $66,2 \%$ (intermediate) sedangkan asam askorbat sebagai kontrol positif sebesar 97,7\% (antioksidan kuat). Dari hasil penelitian dapat disimpulkan bahwa ektrak etanol bee pollen lebah trigona (Trigona itama) memiliki khasiat sebagai antioksidan dengan golongan aktivitas antioksidan (AA) intermediet (sedang).

Kata kunci: Bee pollen, trigona itama, antioksidan, $\beta$-karoten bleaching, spektrofotometri UV Vis

\section{Pendahuluan}

Antioksidan adalah senyawa yang mampu menangkal atau meredam efek negatif oksidan dalam tubuh, bekerja dengan cara mendonorkan satu elektronnya kepada senyawa yang bersifat oksidan sehingga aktifitas senyawa oksidan tersebut dapat dihambat. Antioksidan juga merupakan senyawa yang dapat menghambat reaksi oksidasi, dengan mengikat radikal bebas dan molekul yang sangat reaktif. Akibatnya, kerusakan sel akan dihambat. Antioksidan bermanfaat dalam mencegah kerusakan oksidatif yang disebabkan oleh radikal bebas sehingga mencegah terjadinya berbagai macam penyakit seperti penyakit kardiovaskuler.( Ramadhan, 2015)

Radikal bebas adalah molekul yang kehilangan elektron, sehingga molekul tersebut menjadi tidak stabil dan selalu berusaha mengambil elektron dari molekul atau sel lain. Radikal bebas memiliki reaktivitas yang sangat tinggi dan ditunjukkan oleh sifatnya yang menyerang atau menarik elektron dari senyawa lain disekelilingnya dan mengakibatkan terbentuknya senyawa radikal baru (Winarsi, 2007) 
Bee pollen merupakan salah satu bahan yang mengandung antioksidan alami berupa flavonoid, polifenol dan karotenoid. Karena kandungan bahan kimia komposisinya yang kompleks dan beragam membuat bee pollen mempunyai khasiat yang bermacam-macam, salah satunya adalah sebagai antioksidan.( Fiergiyanti, 2015)

Pengujian aktivitas antioksidan bee pollen lebah trigona (Trigona itama) pada penelitian ini menggunakan metode spektrofotometri uv-vis. Aktivitas antioksidan pada pengujian ini ditentukan oleh oksidasi $\beta$-karoten, asam linoleat dan vitamin $C$ sebagai pembandingnya. Prinsip dari metode ini yaitu pemutihan $\beta$-karoten didasarkan pada hilangnya warna kuning $\beta$ karoten karena reaksi dengan radikal yang terbentuk oleh oksidasi asam linoleat dalam emulsi. Dalam metode ini, $\beta$-karoten mengalami perubahan warna dengan cepat tanpa adanya antioksidan. Radikal bebas asam linoleat yang terbentuk pada abstraksi atom hidrogen dari salah satu gugus metilena diaksinya menyerang molekul $\beta$-karoten yang tidak jenuh. Sebagai akibatnya, $\beta$-karoten akan teroksidasi dan terurai sebagian, kemudian sistem kehilangan gugus kromofor dan warna jingga karakteristiknya, yang dapat dipantau secara spektrofotometri.( Lamberkabel, 2011)

\section{Metode Penelitian}

\section{Tempat dan Waktu Penelitian}

Penelitian ini akan dilakukan di laboratorium Analisa Obat dan Kosmetika Prodi Diploma III Analis Farmasi dan Makanan, Fakultas Kedokteran dan Ilmu Kesehatan Universitas Abdurrab pada bulan Januari 2019.

\section{Alat dan Bahan}

Alat yang digunakan yaitu beaker glass (Pyrex), timbangan analitik, rotary evaporator, spektrofotometer UV-Vis (T60 Uv-Visible Spectrophotometer).

Bahan yang digunakan pada penelitian ini adalah bee pollen lebah trigona (trigona itama), akuades, etanol, asam linoleat, $\beta$ - karoten, asam askorbat, tween 80 , kloroform.

\section{Prosedur Kerja}

\section{a. Pengambilan Bee Pollen}

Bee pollen lebah trigona (Trigona itama) diambil dan dipisahkan dari propolis dan sarangnya. Kemudian bee pollen dimasukkan ke dalam wadah yang bersih dan tertutup rapat. Bee pollen yang didapatkan dikering anginkan pada suhu $25^{\circ} \mathrm{C}$ hingga kering. Setalah itu bee pollen dikumpukan dan ditimbang beratnya.

\section{b. Ekstraksi Bee Pollen}

Sampel bee pollen ditimbang sebanyak (2g), kemudian diekstraksi secara individual dengan menggunakan $15 \mathrm{~mL}$ larutan etanol sebagai pelarut ekstraksi dalam konsentrasi pollen ethanolic extracts (PEE) $70 \%$ pada suhu $70^{\circ} \mathrm{C}$ selama 30 menit dengan agitasi konstan. Setelah itu supernatan dipisahkan dan residu padat diekstrak kembali.

c. Penentuan Aktivitas Antioksidan Ekstrak Etanol Bee Pollen (Lamberkabel, 2011)

Penentuan Panjang Gelombang Maksimum $\beta$-karoten (Carpes, 2007)

1. Pembuatan Larutan Induk $\beta$-karoten 500 ppm 
Sebanyak 25 mg $\beta$-karoten murni ditimbang, kemudian dilarutkan dalam $30 \mathrm{ml}$ petroleum eter di dalam labu ukur $50 \mathrm{ml}$, lalu dicukupkan volumenya hingga $50 \mathrm{ml}$, sehingga diperoleh larutan dengan konsentrasi 500 ppm. Dibuat terlebih dahulu larutan $\beta$-karoten 100 ppm dengan cara pipet $25 \mathrm{ml}$ larutan induk $\beta$-karoten

500 ppm, masukkan ke dalam labu ukur 50 ml. Kemudian cukupkan volumenya dengan petroleum eter hingga tanda batas, kocok hingga homogen.

2. Untuk penentuan panjang gelombang maksimum $\beta$-karoten dilakukan dengan konsentrasi 10 ppm dengan cara dipipet 2,5 ml larutan $\beta$-karoten 100 ppm, masukkan ke dalam labu ukur $25 \mathrm{ml}$. Petroleum eter ditambahkan hingga tanda batas, dihomogenkan. Setelah itu diukur panjang gelombang maksimum dengan spektrofotometer Visibel pada range panjang gelombang 400-800 $\mathrm{nm}$.

d. Pembuatan Emulsi $\boldsymbol{\beta}$-karoten-asam Linoleat (Lamberkabel, 2011)

Aktivitas antioksidan ditentukan oleh oksidasi $\beta$-karoten-asam linoleat. Emulsi $\beta$-karoten-asam linoleat dibuat dengan mencampurkan $1 \mathrm{ml}$ larutan $\beta$-karoten (1mg/ml dalam kloroform) 12,7 ml asam linoleat dan 83,3 mg tween 80. Campuran dihomogenkan hingga terbentuk emulsi kemudian dilarutkan hingga $60 \mathrm{ml}$ akuades dkemudian diaduk hingga terbentuk emulsi.

e. Pembuatan Larutan Uji (Lamberkabel, 2011)

Sebanyak 1,0 ml larutan sampel ditambahkan 2,0 ml emulsi $\beta$ - karoten, asam linoleat dan 2,0 ml akuades kemudian diinkubasi pada suhu $50^{\circ} \mathrm{C}$ selama 5 menit.

f. Pembuatan Blanko(Lamberkabel, 2011)

Untuk pembuatan blanko dibuat dengan mencampurkan 2,1 mL asam linoleat dan 13,8 mg tween 80. Campuran kemudian dihomogenkan hingga terbentuk emulsi, dilarutkan dalam $10 \mathrm{ml}$ akuades.

g. Pembuatan Kontrol Negatif (Lamberkabel, 2011)

Untuk pembuatan kontrol negatif dibuat dengan mencampurkan 2,0 ml emulsi $\beta$-karoten asam linoleat dan 2,0 ml akuades dan 1,0 $\mathrm{ml}$ etanol 96\%.

h. Pembuatan Kontrol Positif (Lamberkabel, 2011)

Untuk pembuatan kontrol positif asam askorbat Sebanyak 1,0 ml asam askorbat (100 ppm) ditambahkan 2,0 ml emulsi $\beta$-karoten, asam linoleat dan 2,0 ml akuades kemudian di inkubasi pada suhu $50^{\circ} \mathrm{C}$ selama 5 menit.

i. Pengukuran Absorbansi (Lamberkabel, 2011)

Setelah itu absorbansi diukur pada panjang gelombang 451,00 nm dengan menggunakan spektrofotometer Visibel. Absorbansi diukur dengan selang interval 15 menit sampai warna $\beta$ karoten memudar (120 menit). Persentase aktivitas antioksidan sampel dibandingkan dengan asam askorbat (vitamin $\mathrm{C}$ ). 
Analisis Data (Lamberkabel, 2011)

Hasil disajikan dalam bentuk nilai persentase (\%) kekuatan antioksidan berdasarkan nilai absorbansi yang didapatkan. Persen aktivitas antioksidan ditentukan dengan menggunakan rumus berikut :

$$
\begin{aligned}
\% A A & =1-\left(A^{0}-A^{120}\right) s \\
& \frac{\left(A^{0} 0-A^{0} 120\right)}{120} \times 100 \%
\end{aligned}
$$

\section{Hasil dan Pembahasan}

\section{Hasil}

Dari penelitian yang telah dilakukan, didapatkan hasil sebagai berikut:

1. Penentuan Panjang gelombang maksimum $\beta$-karoten pada konsentrasi 10 ppm yaitu adalah $451,00 \mathrm{~nm}$.

Tabel 1. Hasil penentuan panjang gelombang maksimum $\beta$-karoten

\section{Panjang Gelombang}

\section{Absorban}

477,00 0,510

451,00 0,625

468,00 0,486

2. Hasil pengukuran absorbansi ekstrak etanol bee polen lebah trigona (Trigona itama), kontrol positif asam askorbat dan kontrol negatif pada menit ke-0 dan menit ke-120 yang didapatkan yaitu: ektrstrak etanol bee polen waktu 0 menit sebesar 0,237, waktu 120 menit yaitu sebesar 0,080. Kontrol negatif waktu 0 menit sebesar 0,103, waktu 120 menit sebesar -0,351. Dan sedangkan kontrol positif (Asam askorbat) waktu 0 menit sebesar 0,249, dan waktu 120 menit sebesar-0,307.

Tabel 2. Hasil absorban sampel ekstrak etanol bee polen lebah trigona (Trigona itama),

\begin{tabular}{|c|c|c|c|}
\hline $\begin{array}{l}\text { Menit } \\
\text { ke- }\end{array}$ & $\begin{array}{c}\text { Absorban } \\
\text { Kontrol negatif }\end{array}$ & $\begin{array}{c}\text { Absorban } \\
\text { Ekstrak bee pollen }\end{array}$ & $\begin{array}{c}\text { Absorban } \\
\text { Asam askorbat }\end{array}$ \\
\hline $\mathbf{0}$ & 0,103 & 0,237 & 0,249 \\
\hline 15 & 0,095 & 0,188 & 0,158 \\
\hline 30 & 0,101 & 0,066 & 0,126 \\
\hline 45 & 0,053 & 0,236 & 0,126 \\
\hline 60 & 0,069 & $0,0,269$ & 0,136 \\
\hline 75 & 0,067 & 0,282 & 0,055 \\
\hline 90 & 0,057 & 0,280 & 0,113 \\
\hline 105 & $-0,287$ & $-0,061$ & $-0,281$ \\
\hline 120 & $-0,351$ & $-0,080$ & $-0,307$ \\
\hline
\end{tabular}
kontrol positif (asam askorbat) dan kontrol negatif 
3. Persentase aktivitas antioksidan (\%AA) yang didapatkan yaitu untuk ekstrak etanol bee polen yaitu sebesar $66,2 \%$ sedangkan asam askorbat yaitu sebesar $97,7 \%$.

Tabel 3. Hasil Persentase aktivitas antioksidan (\%AA)

\begin{tabular}{cccccc}
\hline $\begin{array}{c}\text { Menit } \\
\text { ke- }\end{array}$ & $\begin{array}{c}\text { Absorban } \\
\text { kontrol } \\
\text { negatif }\end{array}$ & $\begin{array}{c}\text { Absorban } \\
\text { ekstrak } \\
\text { etanol bee } \\
\text { polen }\end{array}$ & $\begin{array}{c}\text { Absorban } \\
\text { asam } \\
\text { askorbat }\end{array}$ & $\begin{array}{c}\text { \%AA } \\
\text { ektrak } \\
\text { etanol bee } \\
\text { polen }\end{array}$ & $\begin{array}{c}\text { \%AA } \\
\text { asam } \\
\text { askorbat }\end{array}$ \\
\hline $\mathbf{0}$ & 0,103 & 0,237 & 0,249 & $66,2 \%$ & $97,7 \%$ \\
\hline $\mathbf{1 2 0}$ & $-0,351$ & $-0,080$ & $-0,307$ & & \\
\hline
\end{tabular}

\section{Pembahasan}

Penelitian ini bertujuan untuk mengetahui aktivitas antioksidan ekstrak etanol bee pollen lebah trigona (Trigona itama). Penelitian ini dilakukan dengan menggunakan metode spektrofotometri Uv-Vis. Senyawa antioksidan merupakan inhibitor oksidasi, yang mana cara kerja senyawa antioksidan adalah bereaksi dengan radikal bebas reaktif membentuk radikal bebas tak reaktif yang relatif stabil. Antioksidan menstabilkan radikal bebas dengan melengkapi kekurangan elektron yang dimiliki radikal bebas, dan menghambat terjadinya reaksi berantai dari pembentukan radikal bebas. Dalam suatu sistem biologis terdapat sistem pertahanan tubuh untuk melawan atau meredam radikal bebas. Sistem pertahanan tubuh tersebut didukung oleh zat-zat gizi yang dapat dijadikan sebagai sumber antioksidan salah satunya yaitu bee pollen (serbuk sari) dari lebah trigona (Trigona itama).

Ekstrak etanol bee pollen lebah trigona (Trigona itama) diuji aktivitas antioksidannya dengan menggunakan metode $\beta$-carotene blaching. Pengukuran absorbansi degredasi $\beta$-karoten yang telah diinkubasi bersama dengan ekstrak etanol bee pollen lebah trigona, asam askorbat, dan kontrol negatif dilakukan selama 120 menit dengan interval waktu per 15 menit. Adanya penambahan ekstrak etanol bee pollen yang diduga mengandung antioksidan diharapkan dapat menghambat laju degredasi $\beta$-karoten.Metode $\beta$-carotene blaching merupakan metode untuk mengevaluasi aktivitas antioksidan berdasarkan pada kemampuan antioksidan untuk mencegah peluruhan warna jingga karoten akibat oksidasi dalam sistem emulsi beta karoten-asam linoleat. Dalam pengujian aktivitas antioksidan dengan metode $\beta$-carotene blaching digunakan bahan-bahan utama, seperti beta karoten sebagai indikator aktivitas antioksidan, asam linoleat sebagai sumber radikal bebas, dan senyawa antioksidan ekstrak etanol bee pollen lebah trigona (Trigona itama) sebagai penghambat reaksi oksidasi.

Asam linoleat digunakan sebagai senyawa yang teroksidasi karena memiliki banyak ikatan yang tidak jenuh. Ikatan rangkap yang terputus dari asam linoleat akan menghasilkan radikal bebas yang dapat menyerang ikatan rangkap terkonjugasi. Sedangkan senyawa antioksidan dianalogikan dengan sampel yang diuji, sampel uji dilarutkan dengan menggunakan etanol 70\%. Dengan menggunakan etanol 70\% ini dikarenakan dari penelitian sebelumnya telah teruji bahwa pada konsentrasi $70 \%$ lah memberikan hasil yang lebih bagus 
dibandingkan dengan konsentrasi yang lain. Hasil sampel uji dibandingkan dengan kontrol negatif yang selanjutnya disebut blank yaitu sitem emulsi beta karoten dan asam linoleat yang tidak mengandung antioksidan. Selanjutnya sampel uji yang telah ditambahkan dengan emulsi beta karoten dan asam linoleat akan melalui proses pemanasan yaitu di inkubasi didalam oven pada suhu $50{ }^{\circ}$ C. Akibat pemanasan asam linoleat akan menghasilkan radikal bebas dan radikal peroksida (hidroperoksida) yang akan menyerang ikatan rangkap terkonjugasi yang banyak pada senyawa beta karoten. Ikatan rangkap terkonjugasi ini yang memberikan warna jingga pada beta karoten. Karena senyawa beta karoten banyak kehilangan ikatan rangkap, maka senyawa beta karoten akan mengalami peluruhan atau pemucatan warna yang ditandai dengan menurunnya nilai absorbansi.

Dalam sistem beta karoten-asam linoleat, antioksidan berperan dalam menghambat peluruhan warna jingga karoten. Dengan kata lain senyawa antioksidan akan menghambat proses oksidasi dari asam linoleat dan beta karoten. Senyawa antioksidan akan berikatan dengan radikal bebas yang terbentuk pada

awal reaksi akibat inisiator panas, untuk mencegah reaksi lebih lanjut antara radikal bebas dengan oksigen yang dapat menghasilkan radikal peroksida yang sangat reaktif. Untuk selanjutnya antioksidan juga berfungsi untuk menetralisir radikal peroksida dengan melepaskan atom hidrogen sehingga radikal yang terbentuk selama proses oksidasi tersebut akan terstabilkan akibat berikatan dengan atom hidrogen yang berasal dari senyawa antioksidan yang terdapat dalam sampel uji.

Pada penentuan panjang gelombang maksimum $\beta$-karoten pada konsentrasi $10 \mathrm{ppm}$ didapatkan yaitu 451,00 nm. Hasil yang didapatkan sesuai dengan literatur panjang gelombang maksimum $\beta$-karoten yaitu 451,00 nm.(Carpes, 2007) Aktivitas antioksidan ini diuji dengan mengukur absorbansi dari sampel, kontrol positif (asam askorbat) dan kontrol negatif dengan menggunakan alat spektrofotometer Uv-vis pada panjang gelombang $451 \mathrm{~nm}$. Kemudian dengan data absorbansi akan didapatkan besarnya aktivitas antioksidan dengan menghitung persentase aktivitas antioksidan (\%AA).

Pada pengujian ini digunakan kontrol positif asam askorbat lebih dikenal dengan vitamin C yang mana tujuan menggunakan kontrol positif ini yaitu untuk melihat dan membandingkan aktivitas antioksidan manakah yang lebih bagus antara asam askorbat dan sampel yang diuji. Untuk mengetahui seberapa besar aktivitas antioksidan pada sampel ekstrak etanol bee polen lebah trigona (Trigona itama) dan kontrol positif asam askorbat yaitu dengan menghitung \% Aktivitas Antioksidan yang didapatkan hasil dengan memasukkan data absorbansi pada waktu menit ke 0 dan waktu menit ke 120 yang sebelumnya telah diukur dengan menggunakan alat spektrofotometri Uv-vis.

Untuk uji aktivitas antioksidan dengan menggunakan metode $\beta$-carotene bleaching ini dengan seiring waktu akan mengalami peluruhan atau pemucatan warna yang ditandai dengan menurunnya nilai absorbansi. Dan pada pengujian aktivitas antioksidan pada ektrak etanol bee polen lebah trigona (Trigona itama) didapatkan hasil peluruhan atau pemucatan warna pada larutan sampel ektrak etanol bee polen dan asam askorbat dengan bertambahnya waktu 
pengukuran sampel. Akan tetapi nilai absorban yang didapatkan mengalami naik turun naik dan tidak sesuai dengan terjadinya peluruhan warna karena peluruhan warna ini terjadi diatandai dengan menurunnya nilai absorbansi. Hal ini terjadi mungkin disebabkan faktor-faktor yang dapat mempengaruhi absorbansi, adapun faktor yang dapat mempengaruhi absorbansi meliputi jenis pelarut, $\mathrm{pH}$, suhu, konsentrasi elektrolit yang tinggi dan adanya zat pengganggu.

Pada pengujian ini nilai absorbansi yang didapatkan berbeda hal ini terjadi karena adanya kesalahan pada pembuatan blanko. Pada pembuatan blanko asam linoleat yang dipipet sebanyak 5,0 $\mathrm{mL}$ dan tween 80 ditimbang sebanyak $33 \mathrm{mg}$, seharusnya pada pembuatan blanko asam linoleat yang dipipet yaitu sebanyak 2,1 mL dan tween 80 ditimbang sebanyak 13,8 mg. Dari kesalahan tersebut dapat mempengaruhi hasil absorban yang didapatkan berbeda, sehingga dapat mempengaruhi nilai persentase aktivitas antioksidan (\%AA). Selain itu adanya juga zat pengganggu dari tidak bersihnya saat bekerja. Karena kebersihan juga akan mempengaruhi absorbansi termasuk bekas jari pada dinding tabung harus dibersihkan dengan kertas tisu dan hanya memegang bagian ujung atau tabung sebelum pengukuran. Karena larutan yang digunakan pada pengujian ini ada menggunakan larutan emulsi maka sifat dari larutan ini pasti berminyak. Karna minyak ini sulit untuk dihilangkan kemungkinan penyebab naik turunya absorbansi karena adanya zat pengganggu yaitu sisa minyak dari larutan sebelumnya di dalam kuvet yang ternyata belum bersih sepenuhnya sehingga dapat mempengaruhi nilai absorbasnsi pada pengukuran yang selanjutnya. (Gandjar, 2012)

Menurut Hassimotto (2005) didalam Tahir set al., 2017, daya AA (aktivitas antioksidan) metode $\beta$-carotene bleaching digolongkan menjadi tiga tingkat yaitu antioksidan kuat $(>70 \%)$, intermediate (40-70\%), dan lemah ( $<40 \%) . \%$ AA adalah Persentase Aktivitas Antioksidan yang mana menunjukkan kemampuan suatu antioksidan dalam menghambat radikal bebas (dalam bentuk \%). Persen aktivitas antioksidan menunjukkan banyaknya atom hidrogen dari senyawa antioksidan yang menangkap radikal bebas.( Putri, 2015)

Berdasarkan data hasil penentuan \% aktivitas antioksidan ekstrak etanol bee polen lebah trigona (Trigona itama) dengan menggunakan metode $\beta$-carotene bleaching maka, diperoleh \%AA ekstrak etanol bee polen sebesar $66,2 \%$ sedangkan asam askorbat sebesar 97,7\%. Hasil yang didapatkan aktivitas antioksidan asam askorbat sebagai kontrol positif lebih tinggi dibandingkan dengan ekstrak etanol bee polen lebah trigona (Trigona itama) terhidrolisis. Namun hal ini tetap menunjukkan bahwa ekstrak etanol bee polen lebah trigona memiliki \% aktivitas antioksidan dengan kategori antioksidan intermediate yaitu 40-70\%.

\section{Kesimpulan}

Dari hasil penelitian yang telah didapatkan maka dapat disimpulkan bahwa uji aktivias antioksidan ekstrak etanol bee polen lebah trigona (Trigona itama) dengan menggunakan metode $\beta$-carotene bleaching diperoleh yaitu sebesar $66,2 \%$ termasuk golongan aktivitas antioksidan intermediate yaitu $40-70 \%$ dan asam askorbat sebagai kontrol positif yaitu sebesar $97,7 \%$ termasuk ke dalam golongan aktivitas antioksidan kuat (>70\%). Jadi aktivitas antioksidan kontrol positif lebih besar dibandingkan ekstrak etanol bee pollen. 
JOPS (Journal Of Pharmacy and Science)

Vol 3 No 1 Desember 2019

\section{REFERENSI}

Carpes, T.S., Begnini, R., De Maties, S., Masson, L.M. 2007. Study of Preparations of Bee Pollen Extracts, Antioxidant and Antibacterial Activity. Journal Cienc. Agrotec., Lavras, Volume (31): 1818-1825

Chandra, B., Zulharmita., Handayani, H.D.A. 2017. Analisis Kandungan Beta Karoten Pada Daun Bayam Merah (Amaranthus hybridus L.) dengan Metode Spektrofotometri

Departemen Kesehatan Republik Indonesia. 2014. Farmakope Indonesia, Edisi V. Jakarta

Fiergiyanti, N., Erwin., dan Syafrizal. 2015. Analisis Fitokimia dan Toksisitas (Brine Shrimp Lethality Test) Ekstrak Serbuk Sari dari Trigona incisia. Jurnal Kimia Mulawarman, Volume 13 (1): 32-34

Gandjar, I. G., dan Abdul, R. 2012. Analisis Obat Secara Spektroskopi dan Kromatografi. Yogyakarta: Pustaka Pelajar.

Hendayana., Semar., Asep, K., Sumarna., Supriatna, A.1994. Kimia Analitik Instrumen. Semarang: IKIP Semarang Press.

Lamberkabel, J.S.A. 2011 Mengenal Jenis-Jenis Lebah Madu, Produk-Produk Dan Cara Budidayanya. Jurnal Ilmu Pengetahuan dan Teknologi, Volume 9 (1): 70-77

Putri, M. P., dan S. Yunita, H. 2015. Analisis Kadar Vitamin C Pada Buah Nanas Segar (Ananas Comosus (L) Merr) dan Buah Nanas Kaleng Dengan Metode Spektrofotometri UV-VIS. Jurnal Wiyata, Volume 2 (1): 34-38

Ramadhan, P. 2015. Mengenal Antioksidan. Yogyakarta: Graha Ilmu

Salamah N, Nurushoimah. Uji Akitivitas Antioksidan Ekstrak Etanol Herba Pegagan (Centella asiatica (L). Urb) dengan Metode Penghambatan Degradasi Betakaroten. Farmasi Sains, 2014:2(4)

Tahir, M., Abidin, Z., Sukmawati,N. 2017. Antioxidant Activity Of Hydrolyzed Black Soybean (Glycine Soja Linn.Sieb) By $\beta$-Carotene Bleaching.Journal of Pharmaceutical and Medicinal Sciences, Volume 2 (1):1-4

Winarsi, H. 2007. Antioksidan Alami dan Radikal Bebas. Yogyakarta: Kanisius

Yoza, D., P. Rengi, dan U.M. Tang. 2013. Identifikasi Jenis Lebah Trigona dan Seberannya di Taman Nasional Tesso Nilo dan Sekitarnya. Riau, Indonesia: UR Press 